\title{
The Relationship between Tropical Easterly Waves and Surges over the Gulf of California during the North American Monsoon
}

\author{
RYAN D. FULLER \\ Northland College, Ashland, Wisconsin
}

DAVID J. STENSRUd

NOAA/National Severe Storms Laboratory, Norman, Oklahoma

(Manuscript received 6 August 1999, in final form 2 December 1999)

ABSTRACT

\begin{abstract}
Coastally trapped disturbances, which occur over the Gulf of California and are commonly referred to as gulf surges, are an important mechanism in the transport of low-level moisture into the southwestern United States. To determine whether or not gulf surges develop in association with the passage of tropical easterly waves, as hypothesized in previous studies, standard surface observations and European Centre for Medium-Range Weather Forecasts reanalysis data during the months of July and August over a 14-yr period are examined. Results indicate that tropical easterly wave troughs often cross western Mexico 1-3 days prior to surge onset at Yuma, Arizona, indicating a strong correlation between these two events. This analysis documents yet another mechanism by which the Tropics influences convection in the midlatitudes.
\end{abstract}

\section{Introduction}

The North American monsoon is a significant feature in the climate of the southwestern United States and Mexico during the summer months. Rainfall in northwestern Mexico during the months of July through September accounts for between $60 \%$ and $80 \%$ of the total annual rainfall, while rainfall in Arizona for these same months accounts for over $40 \%$ of the total annual rainfall (Douglas et al. 1993). Deep convection during the monsoon season produces frequent damaging surface winds and flash flooding and is a difficult forecast problem (Dunn and Horel 1994; McCollum et al. 1995).

The importance of low-level moisture to the development of convection over the southwestern United States has been emphasized in many studies (Bryson and Lowry 1955; Green and Sellers 1964; Adang and Gall 1989). Thus, any phenomenon that is associated with low-level moisture transport plays an important role in developing the environment necessary for the occurrence of deep convection. One such mesoscale feature is a gulf surge (Fig. 1), a coastally trapped disturbance that propagates northward along the Gulf of California (Stensrud et al. 1997). A strong moisture gradient is often seen in association with a gulf surge as it passes

Corresponding author address: Dr. David J. Stensrud, National Severe Storms Laboratory, 1313 Halley Circle, Norman, OK 73069. E-mail: David.Stensrud@nssl.noaa.gov into Arizona, with higher moisture values behind (to the south of) the leading edge of the surge. Both observational and modeling studies suggest that gulf surges help to increase low-level moisture significantly in the southwestern United States, often providing the one missing ingredient needed for deep convection (Stensrud et al. 1995; McCollum et al. 1995).

Gulf surges have a number of common characteristics that have been found observationally by both Hales (1972) and Brenner (1974):

- Surface weather changes include a drop in temperature, a rise in dewpoint temperature, a wind shift with an increased southerly wind component, lower visibility, a rise in sea level pressure, and increasing lowlevel cloudiness.

- The low-level cooling and moistening produced by a surge are a maximum just above the surface and decrease in intensity with height.

- The amount of low-level cooling and the sharpness of the change decrease as the surge spreads out across the low desert after moving into Arizona.

- Thunderstorm activity in Arizona increases markedly after strong surges occur.

Hales (1972) further relates the intensity of the gulf surge to both the surface temperature of the Mojave Desert area and the amount of cloud cover associated with the development of the surge over the Gulf of California. He finds that stronger surges occur in as- 


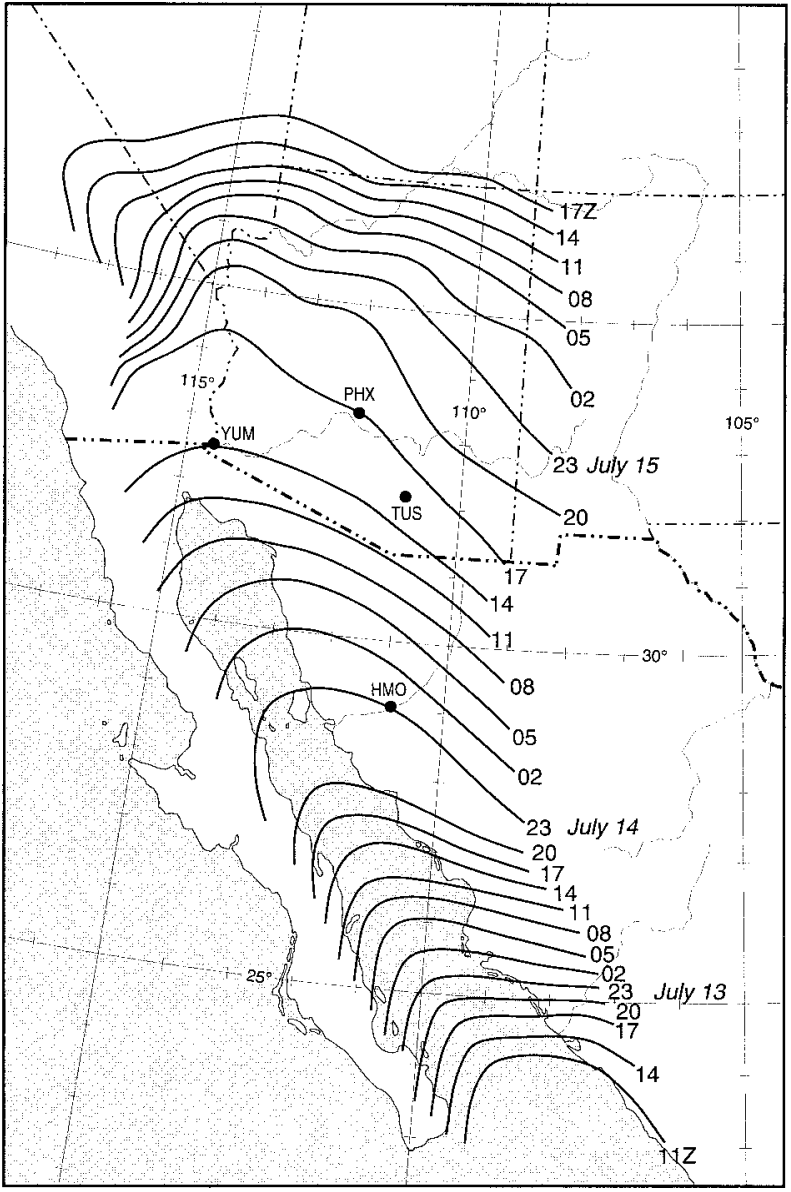

FIG. 1. Isochrones of the leading edge of a moisture surge from 13 to 16 Jul 1972 (after Brenner 1974). Locations of Yuma (YUM), Phoenix (PHX), and Tucson (TUS), AZ, and Hermosillo (HMO), Mexico, are indicated.

sociation with warmer temperatures over the Mojave Desert and larger cloud areas over the gulf. Strong surge passages into Arizona appear to be related to tropical disturbances passing by the southern Gulf of California.

A recent study by Stensrud et al. (1997) appears to confirm this connection between gulf surges and tropical disturbances during the monsoon season of 1990. Using output from a mesoscale numerical model and observations, they document that out of six observed surge events, five of these surge events are preceded by the passage of a tropical easterly wave trough across western Mexico. Their results also suggest a potential influence of midlatitude westerly wave passage on the strength of the surge events, such that when the passage of a westerly wave trough across the western United States precedes the passage of an easterly wave trough across western Mexico by several days, the resulting gulf surge is strong. This strong response is attributed to the midlatitude westerly wave trough producing a stronger than normal low-level stable layer over the Gulf of California region.
Unfortunately, Stensrud et al. (1997) only use data from a 32-day period to examine the relationships between gulf surges, tropical easterly waves, and midlatitude westerly waves. While their results are very suggestive, further evidence is needed to establish how often the development of a gulf surge is related to tropical and midlatitude wave passages. Therefore, meriodinal wind data from the European Centre for Medium-Range Weather Forecasts (ECMWF) Reanalysis Project are examined over a 14-yr period to document the times of wave passage across western North America during the months of July and August. In addition, surface observations from Yuma, Arizona, are used to define the onset time for surge events that propagate into the southwestern United States. As is shown below, a comparison of these two datasets suggests that tropical easterly waves are intimately tied to the development of gulf surges, with tropical easterly waves passing across western Mexico 1-3 days prior to the onset of gulf surges in Arizona.

The method by which surges are identified in surface data is described in section 2 , followed by a description of how westerly and easterly waves are identified in section 3. The results of these analyses are found in section 4, with a final discussion in section 5 .

\section{Identification of surges}

The shallow depth of a gulf surge (Douglas 1995), and lack of upper-air data near the northern end of the Gulf of California, makes the routine identification of surge events dependent entirely upon surface data. In particular, Stensrud et al. (1997) show that surge events can be identified using surface data from Yuma. Thus, hourly surface observations from Yuma are used to diagnose the occurrence of gulf surges during the months of July and August from 1979 through 1993, ${ }^{1}$ the two months when the monsoon season is most active (Douglas et al. 1993). Yuma is located in the far southwestern corner of Arizona $\left(32.67^{\circ} \mathrm{N}, 114.60^{\circ} \mathrm{W}\right)$ at an elevation of $63 \mathrm{~m}$ above mean sea level, and is located approximately $100 \mathrm{~km}$ north of the northern end of the Gulf of California (Fig. 1). Admittedly, by using only surface data from Yuma, some gulf surges may not be identified, since surges do not always propagate into Arizona, or may not extend far enough westward from the Sierra Madre Occidental to be well observed at this location (Andrus 1996). It is possible that weaker surges are not captured at all using this particular dataset. However, the observations at Yuma remain the most reliable source of operational data available to diagnose surges and are used to define the surge events for this study.

The hourly surface observations are suggestive of

\footnotetext{
${ }^{1}$ Surface data are unavailable for 1992, yielding a total of 14 years' worth of data during for these two months of analysis.
} 
surges on a number of days, owing to the rapid increases in surface dewpoint temperatures, one of the characteristics of surge passage documented by Hales (1972) and Brenner (1974). However, in this desert region the diurnal cycle of dewpoint temperature is large and can easily be mistaken as signaling a surge event. Since surges typically persist for several days, one method to remove the influence of the diurnal cycle is to examine the day-to-day persistence in the maximum dewpoint temperatures. Therefore, days of surge onset are identified in the surface data as rapid increases in surface dewpoint temperature in which the maximum daily dewpoint temperatures remain at an elevated value, which exceeds $60^{\circ} \mathrm{F}\left(15.6^{\circ} \mathrm{C}\right)$, over the following several days. This $60^{\circ} \mathrm{F}$ threshold is chosen in order to be representative of air from the Gulf of California (see Stensrud et al. 1995). In addition, the surface $(10 \mathrm{~m})$ wind speeds on the day of the initial, rapid dewpoint temperature increase must be reported as southerly and exceed $4 \mathrm{~m}$ $\mathrm{s}^{-1}$ for at least one reporting time. These criteria are almost identical to those used by Stensrud et al. (1997), except that they used a minimum dewpoint temperature of $65^{\circ} \mathrm{F}\left(18.3^{\circ} \mathrm{C}\right)$. The $60^{\circ} \mathrm{F}$ minimum dewpoint temperature is used in this study to help identify surges that occur in early July.

Strong and weak surges are identified by examining the change in maximum dewpoint temperature over the 3 days after surge onset at Yuma. If the maximum dewpoint temperature decreases during this 3-day period, then the surge is categorized as being weak. In contrast, if the maximum dewpoint temperature increases during this 3-day period, then the surge is categorized as being strong. This taxonomy is more closely associated with the duration of a surge than with any initial change in moisture associated with the surge leading edge.

An example of the time series of Yuma surface observations from July 1986 illustrates the typical signals associated with both strong and weak surge events (Fig. 2 ). Five surges are observed during the month and are identified by the rapid increases in dewpoint temperatures, which occur in conjunction with stronger $(>4 \mathrm{~m}$ $\mathrm{s}^{-1}$ ) southerly winds, and in which the maximum dewpoint temperatures remain elevated for the following several days when compared to the presurge values Note that in order for a surge to be identified, several days with relatively lower dewpoint temperatures must be observed at Yuma prior to the surge. If the dewpoint temperatures remain high throughout a longer time period, it is impossible to distinguish any surge events, since increases in the dewpoint temperature values are the most distinguishing characteristic of surges. Thankfully, this occurs infrequently at Yuma.

Although care has been taken in the identification of surge events, it is clear that there are many ambiguities in the available data (from only one surface site) that may lead to errors in the precise date of surge onset. However, for most cases the dramatic increase in dewpoint temperature that occurs in conjunction with a

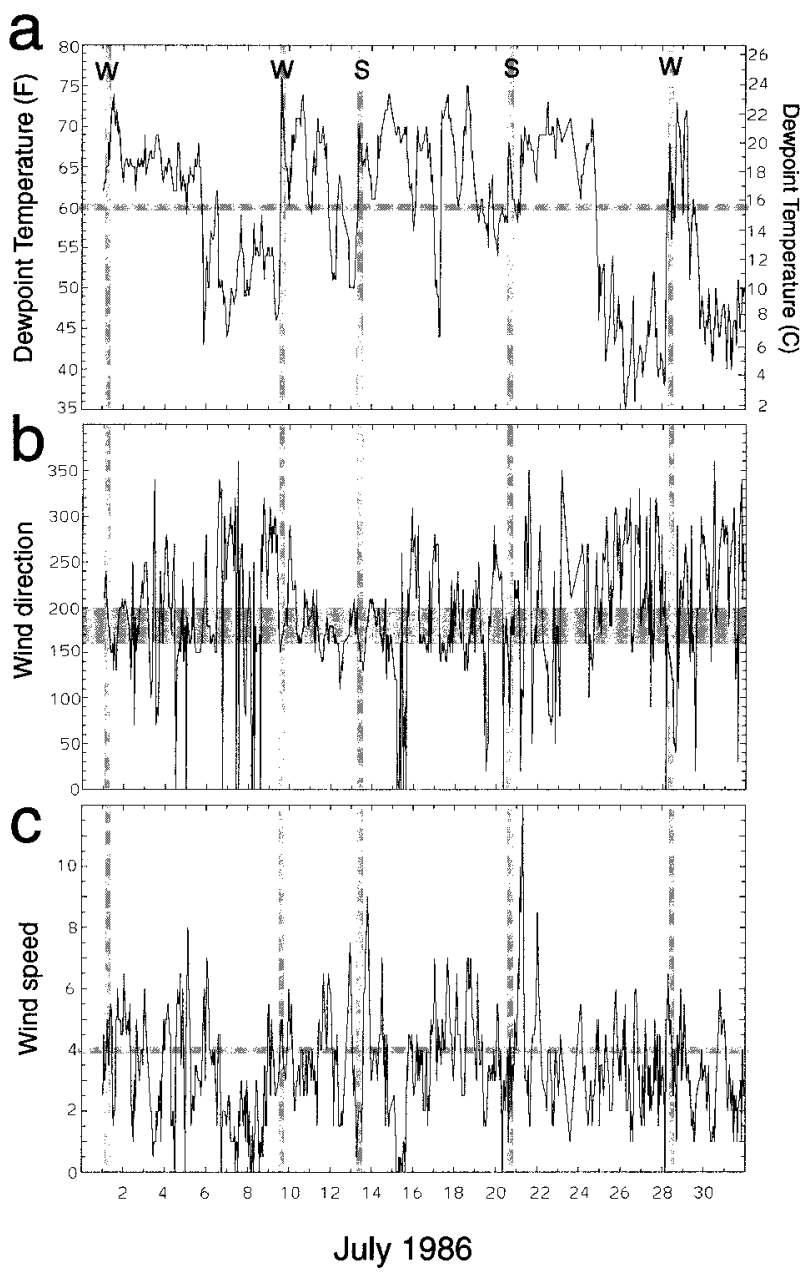

FIG. 2. Hourly values of (a) dewpoint temperature $\left({ }^{\circ} \mathrm{F}\right.$ and $\left.{ }^{\circ} \mathrm{C}\right)$, (b) wind direction $\left({ }^{\circ}\right)$, and (c) wind speed $\left(\mathrm{m} \mathrm{s}^{-1}\right)$ observed at Yuma during the entire month of Jul 1986. Surge onset is denoted by the vertical shaded line, with $\mathrm{S}$ denoting a strong surge and $\mathrm{W}$ denoting a weak surge. The horizontal line in (a) denotes the $60^{\circ} \mathrm{F}$ dewpoint temperature, the horizontal shaded region in (b) highlights where the winds are nearly southerly, and the horizontal line in (c) denotes the $4 \mathrm{~m} \mathrm{~s}^{-1}$ wind speed.

surge is difficult to misanalyze. During the 14-yr period examined a total of 85 surges are identified, of which $48(56 \%)$ are identified as being strong, for an average of nearly three surges during each month.

To examine the validity of using only one surface site to identify surges, hourly surface data from Phoenix, Arizona (location noted on Fig. 1), are also examined and the days of surge onset identified. A comparison of the results indicates that over half of the surges identified with Yuma surface data are also seen clearly in the Phoenix surface data within the next $24 \mathrm{~h}$. Many of the remaining cases at Phoenix are associated with persistent, relatively high dewpoint temperatures in which no clear signals of a surge could be identified. This comparison provides some confidence that the surges iden- 
tified at Yuma are reliable and have operational significance.

\section{Identificaton of tropical easterly and midlatitude westerly waves}

The data used to identify tropical easterly waves are the $850-\mathrm{hPa}$ meriodinal wind data from the ECMWF Reanalysis Project, which are available at 24-h increments from 1979 to 1993 with a horizontal resolution of $2.5^{\circ}$. As with the surface data, only data from July and August are examined. One difficulty with this analysis is that the $850-\mathrm{hPa}$ level is not optimal for the identification of easterly waves. Reed et al. (1977) have shown that tropical easterly waves are best defined using wind data at $700 \mathrm{hPa}$, a result also found in model data by Stensrud et al. (1997). In addition, several terrain features in the Caribbean and Central America extend to near or above $850 \mathrm{hPa}$, disrupting the wave signal at this level for lower latitudes. Unfortunately, $700-\mathrm{hPa}$ meridional wind data are not available in this particular ECMWF dataset.

Tropical easterly waves are identified using Hovmöller diagrams of the meridional wind speed as shown in Stensrud et al. (1997). These are longitudetime diagrams and are produced for latitudes between $10^{\circ}$ and $22.5^{\circ} \mathrm{N}$, and longitudes between $65^{\circ}$ and $130^{\circ} \mathrm{W}$, and the times of wave trough passages across $110^{\circ} \mathrm{W}$, the longitude of the eastern shore of the Gulf of California, are identified. Over the 14-yr period, a total of 85 easterly waves are seen in the reanalysis dataset, averaging a little over three per month (Fig. 3). A typical wave moves westward at between 6 and $8 \mathrm{~m} \mathrm{~s}^{-1}$ and has a wavelength of $2500-3800 \mathrm{~km}$, very similar to the characteristics of these waves observed over eastern Atlantic (Reed et al. 1977). Many of the waves are easily seen in the Hovmöller diagrams across the entire latitude belt examined $\left(10^{\circ}-22.5^{\circ} \mathrm{N}\right)$, but some waves only appear clearly over a smaller latitudinal band (e.g., the earliest two waves shown in Fig. 3 are not seen below $20^{\circ} \mathrm{N}$ ). These differences may be due to the disruption of the wave features by the terrain, but there are a number of cases where terrain is clearly not influencing the wave signal. It may be that these differences in the latitudinal extent of the tropical easterly waves are indicative of the variety of background flow regimes found over the western Atlantic. It is also possible that some of the easterly disturbances originate in the midlatidues as westerly waves that move around the climatological, summertime high pressure system over North America, thereby entering into the region of easterly flow to the south of the high.

The westerly waves are also identified using Hovmöller diagrams, but using data from $200 \mathrm{hPa}$ at $40^{\circ} \mathrm{N}$ (Fig. 4). The westerly waves are fewer in number than the easterly waves, with only 37 wave passages indicated, averaging slightly more than one per month. In addition, there are several years in which no westerly

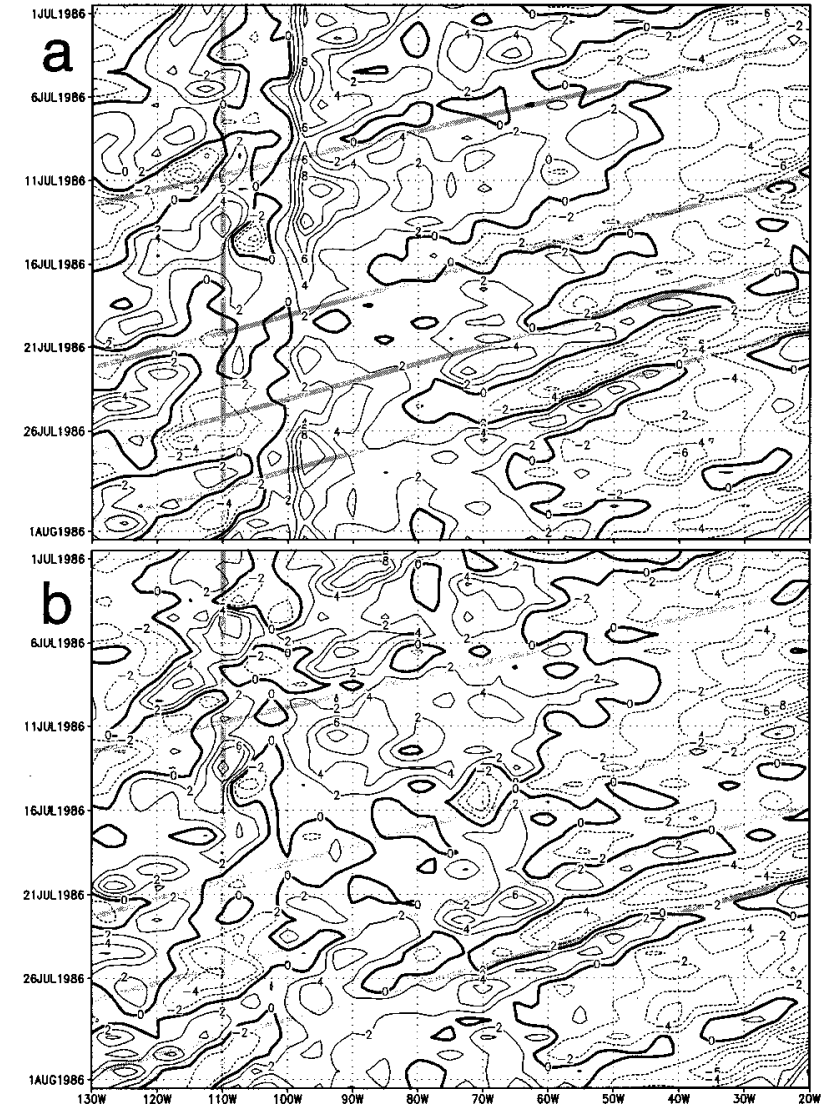

FIG. 3. Hovmöller longitude-time diagram of the 850 -hPa meridional wind component ( $\mathrm{m} \mathrm{s}^{-1}$ ) along (a) $22.5^{\circ} \mathrm{N}$ and (b) $20^{\circ} \mathrm{N}$ during Jul 1986. Contour interval is $2 \mathrm{~m} \mathrm{~s}^{-1}$ with the zero value emphasized. Easterly waves indicated by the diagonal zone of coherent meridional wind speeds, with the wave troughs identified by the diagonal shaded line. Troughs indicated by a change from northerly (dashed lines) to southerly (solid lines) winds as time increases. The vertical shaded line is $110^{\circ} \mathrm{W}$. The earlier waves are better defined at the higher latitude. Terrain effects may be modifying the wind field between $75^{\circ}$ and $105^{\circ} \mathrm{W}$.

waves are seen in the dataset, owing to the development of a strong ridge over the western United States.

\section{Results}

Once the times of the westerly and easterly wave trough passages and surge onsets are determined, the relative timing of these three events are examined. In Stensrud et al. (1997) a conceptual model for surge development is proposed in which the following takes place:

1) A midlatitude disturbance passes through western North America producing enhanced subsidence in its wake. This enhanced subsidence results in a stronger than normal low-level stable layer over the Gulf of California region.

2) An easterly wave moves across central America, and the convergence and upward motion associated with 


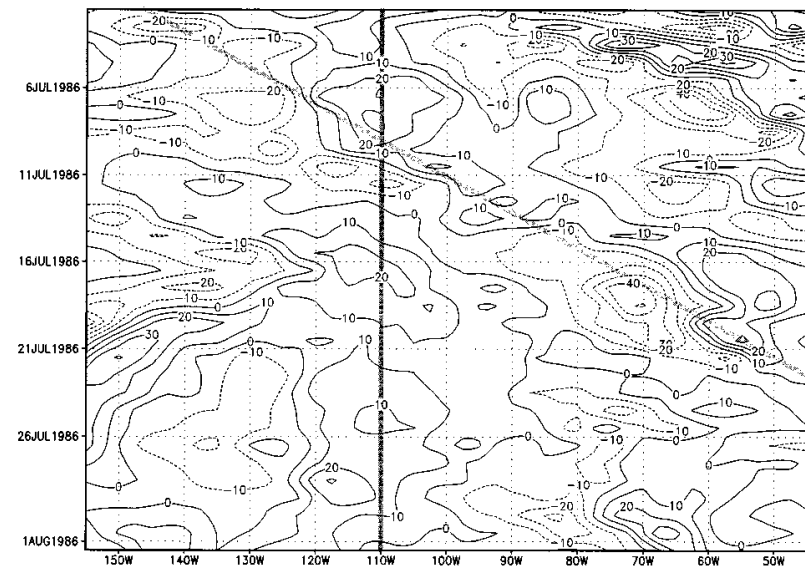

FIG. 4. Hovmöller longitude-time diagram of the 200-hPa meridional wind component $\left(\mathrm{m} \mathrm{s}^{-1}\right)$ along $40^{\circ} \mathrm{N}$ during Jul 1986. Contour interval is $10 \mathrm{~m} \mathrm{~s}^{-1}$. The westerly wave is indicated by the diagonal zone of coherent meridional wind speeds, with the wave trough identified by the diagonal shaded line. Troughs indicated by a change from southerly (solid lines) to northerly (dashed lines) winds as time increases. The vertical shaded line is $110^{\circ} \mathrm{W}$.

the passage of the wave trough initiates convection in the southern or middle Gulf of California.

3) Low-level, cold outflows caused by deep convection over the gulf region, or possibly just low-level convergence associated with the easterly wave, initiates the gulf surge. A number of physical mechanisms can produce the general characteristics of these surge events, including ageostrophic downgradient flow (Overland 1984; Mass and Albright 1985; Colle and Mass 1995), topographically trapped gravity currents (Baines 1980; Hoinka and Volkert 1992), topographic Rossby and shelf waves (Rhines 1970; Pedlosky 1987; Hsu 1987), and Kelvin waves (Gill 1982; Dorman 1985; Reason and Steyn 1992). Skamarock et al. (1999) suggest that coastally trapped disturbances often initially appear to be Kelvin waves that steepen into a gravity current-like feature, making the assessment of the physical mechanisms involved dependent upon the time at which the coastally trapped disturbance is observed.

4) As the surge moves northward into Arizona, it becomes more difficult to track and loses its identity.

This conceptual model suggests that we must look for a particular sequence of these three events. We begin by examining the relationship between tropical easterly wave passage and the onset of surges as observed at Yuma.

Since the easterly waves defined in the ECMWF dataset can occur at a variety of latitude values, and it can take a day or two for a surge to move up the Gulf of California and into Arizona (see Fig. 1), a time window of 3 days between easterly wave trough passage and surge onset is chosen. Therefore, if the onset of a gulf surge is observed at Yuma within 3 days after the passage of the easterly wave trough across $110^{\circ} \mathrm{W}$, then the
TABLE 1. Contingency tables of forecast and observed surge onsets during the months of Jul and Aug. Surge onsets are forecast to occur during a 3-day window after the passage of a tropical easterly wave across western Mexico $\left(110^{\circ} \mathrm{W}\right)$ as identified using the $850-\mathrm{hPa}$ meridional wind component from ECMWF analyses. Observed surge onsets diagnosed using surface observations from Yuma, AZ.

\begin{tabular}{lcrr}
\hline \hline & & \multicolumn{2}{c}{ Observed } \\
\cline { 3 - 4 } & Forecast & Yes & No \\
\hline Jul & Yes & 35 & 15 \\
\multirow{2}{*}{ Aug } & No & 9 & 115 \\
& Yes & 28 & 7 \\
& No & 13 & 128 \\
\hline
\end{tabular}

two events are defined as being related. If a surge does not occur within this 3-day time window, then the events are not related to each other. Days in which it is impossible to determine whether or not a surge occurs at Yuma are neglected (these occur when the dewpoint temperatures at Yuma are consistently high, indicating persistent southerly flow into Arizona). A total of 434 days are contained within each month of this 14-yr period, and only $30 \%$ of these days are examined for the onset of gulf surges.

Results for both months indicate that of the 85 surge onsets, 63 occur in association with the passage of tropical easterly waves. There are also 22 occasions when tropical easterly waves pass across western Mexico and no surge is observed at Yuma. The remaining days are divided into 3-day intervals to define the number of time windows for which no surges are forecast. If these data are used to construct a $2 \times 2$ contingency table (Table $1)$, then we find that the relationship between tropical easterly wave passage and surge onset is highly correlated. This relationship is quantified by using the probability of detection (POD), the false alarm rate (FAR), and the Heidke skill score (HSS; see Wilks 1995). Results indicate that the POD is 0.8 and 0.7 , respectively, for July and August, and the FAR is 0.3 and 0.2 , respectively. These values indicate a good ability to detect surges without producing too many false alarms. However, a better statistic to examine is the HSS, which incorporates an estimate of the hit rate that would be achived by random forecasts. Perfect forecasts receive a HSS of one, forecasts equivalent to that achieved by random chance receive a HSS of zero, and forecasts worse than random chance receive a negative HSS. Results indicate HSS values of 0.65 for July, and 0.66 for August, both of which are significantly greater than would be expected by a random forecast. While this analysis cannot be used to determine cause and effect, the relationship between the passage of tropical easterly wave troughs and surge onset at Yuma a few days later is very suggestive that tropical easterly waves influence the development of gulf surges.

The data also indicate a relationship between the passage of westerly waves and the subsequent strength of the gulf surge. Out of the 85 surge events, only 15 are 


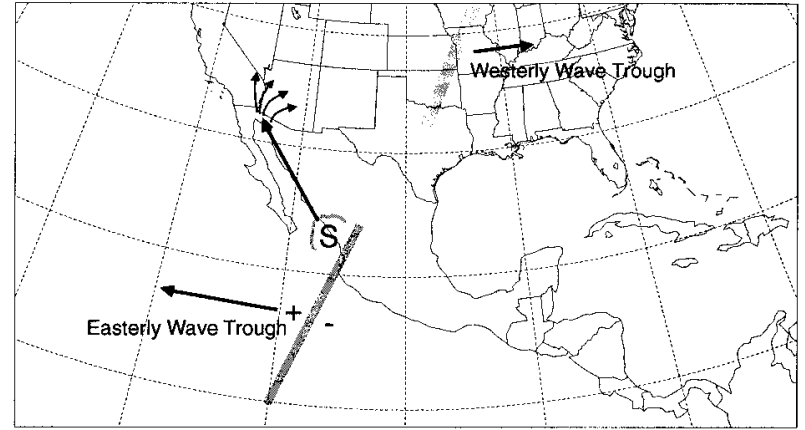

FIG. 5. Conceptual model of the initiation and propagation of gulf surge events as suggested by this study and Stensrud et al. (1997). Letter $\mathrm{S}$ denotes the area of surge initiation, with the diagonal arrow indicating the direction of surge propagation. The \pm indicate regions of upward/downward motion associated with the easterly wave trough, while the arrow indicates direction of movement of the trough.

preceded by a passage of a westerly wave during a three day period prior to easterly wave passage. Of these, 11 westerly wave passages are associated with strong surge events and 4 are associated with weak surge events. Therefore, while there appears to be a relationship between the passage of westerly waves and the strength of the subsequent gulf surge, as suggested by Stensrud et al. (1997), this phase relationship between westerly and easterly waves occurs only once a year on average. Surge intensity must also be influenced by other factors.

\section{Discussion}

We have shown that over a $14-y r$ period there is a consistent relationship between the passage of tropical easterly wave troughs across western Mexico and surge onset observed at Yuma, Arizona, within a 3-day period following trough passage. While it is difficult to argue cause and effect from these data alone, the relative timing between the passage of a tropical easterly wave trough and the onset of a gulf surge is sufficient to give credence to the conceptual model proposed by Stensrud et al. (1997) as outlined in the preceeding section (see Fig. 5). Indeed, the influence of tropical easterly waves on surges is suggested by Hales (1972), although the exact mechanisms by which these two features are related is not described. The surface observations and reanalysis data also show that surges can occur without the passage of an easterly wave trough, indicating that other mechanisms are involved of which there is little understanding at present.

From a forecast perspective, these results suggest that if operational numerical weather prediction models can forecast tropical easterly waves, then it should be possible to predict the occurrence of a gulf surge with a relatively high degree of accuracy. While the results presented herein do not allow one to predict the precise day of surge arrival in Arizona, the ability to predict a surge within a 3-day period should have operational forecast value. A potential difficulty with this approach in the United States is that much of the operational numerical model output routinely available to forecasters stops at $20^{\circ} \mathrm{N}$ latitude, which is too far north to capture tropical easterly wave signals with certainty.

This analysis also suggests that there is yet another mechanism by which the Tropics is able to communicate with the midlatitudes. Observational studies indicate that gulf surges provide the moisture needed for summer thunderstorms in Arizona and, thus, help to define the northern extent of the North American monsoon. It is not yet clear how important gulf surges are to the monsoon convection in northwestern Mexico. Future studies are needed to determine more quantitatively the influence of gulf surges on the northern extent of the North American monsoon.

Acknowledgments. This work was largely accomplished when the first author (RDF) was in the Research Experimental for Undergraduates (REU) at the Oklahoma Weather Center during the summer of 1998. Major funding for the REU program was provided by the National Science Foundation. Additional funding was provided by the NSSL, the Center for the Analysis and Prediction of Storms, the Cooperative Institute for Mesoscale Meteorological Studies, and the School of Meteorology at the University of Oklahoma. We thank the National Center for Atmospheric Research/Data Support Services Division for providing the surface data, and the European Centre for Medium-Range Weather Forecasts for providing the reanalysis data, upon which the results of this study are largely based. We are also grateful for the computer graphics provided by Joan O'Bannon of NSSL.

\section{REFERENCES}

Adang, T. C., and R. L. Gall, 1989: Structure and dynamics of the Arizona monsoon boundary. Mon. Wea. Rev., 117, 1423-1437.

Andrus, D. S., 1996: An observational and modeling study of two Gulf of California surge events. M.S. thesis, School of Meteorology, College of Geosciences, University of Oklahoma, 139 pp. [Available from School of Meteorology, 100 E. Boyd Street, Room 1310, Norman, OK 73019-0628.]

Baines, P. G., 1980: The dynamics of the southerly buster. Aust. Meteor. Mag., 28, 175-200.

Brenner, I. S., 1974: A surge of martime tropical air-Gulf of California to the southwestern United States. Mon. Wea. Rev., 102, 375-389.

Bryson, R. A., and W. P. Lowrey, 1955: Synoptic climatology of the Arizona summer precipitation singularity. Bull. Amer. Meteor. Soc., 36, 329-339.

Colle, B. A., and C. F. Mass, 1995: The structure and evolution of cold surges east of the Rocky Mountains. Mon. Wea. Rev., 123, 2577-2610.

Dorman, C. E., 1985: Evidence of Kelvin waves in California's marine layer and related eddy generation. Mon. Wea. Rev., 113, 827-839.

Douglas, M. W., 1995: The summertime low-level jet over the Gulf of California. Mon. Wea. Rev., 123, 2334-2347.

—, R. A. Maddox, K. Howard, and S. Reyes, 1993: The Mexican monsoon. J. Climate, 6, 1665-1677. 
Dunn, L. B., and J. D. Horel, 1994: Prediction of central Arizona convection. Part II: Further examination of the Eta Model forecasts. Wea. Forecasting, 8, 508-521.

Gill, A. E., 1982: Atmosphere-Ocean Dynamics. International Geophysics Series, Vol. 30, Academic Press, 662 pp.

Green, C. R., and W. D. Sellers, Eds., 1964: Arizona Climate. The University of Arizona Press, 503 pp.

Hales, J. E., Jr., 1972: Surges of maritime tropical air northward over the Gulf of California. Mon. Wea. Rev., 100, 298-306.

Hoinka, K. P., and H. Volkert, 1992: Fronts and the alps: Findings from the front experiment. Meteor. Atmos. Phys., 48, 51-75.

Hsu, H. H., 1987: Propagation of low-level circulation features in the vicinity of mountain ranges. Mon. Wea. Rev., 115, 18641891.

Mass, C. F., and M. D. Albright, 1985: A severe windstorm in the lee of the Cascade Mountains of Washington State. Mon. Wea. Rev., 113, 1261-1281.

McCollum, D. M., R. A. Maddox, and K. W. Howard, 1995: Case study of a severe mesoscale convective system in central Arizona. Wea. Forecasting, 10, 643-665.
Overland, J. E., 1984: Scale analysis of marine winds in straits and along mountainous coasts. Mon. Wea. Rev., 112, 2532-2536.

Pedlosky, J., 1987: Geophysical Fluid Dynamics. Springer-Verlag, $710 \mathrm{pp}$.

Reason, C. J., and D. G. Steyn, 1992: The dynamics of coastally trapped mesoscale ridges in the lower atmosphere. J. Atmos. Sci., 49, 1677-1692.

Reed, R. J., D. C. Norquist, and E. E. Recker, 1977: The structure and properties of African wave disturbances as observed during phase III of GATE. Mon. Wea. Rev., 105, 317-333.

Rhines, P. B., 1970: Edge-, bottom-, and Rossby waves in a rotating stratified fluid. Geophys. Fluid Dyn., 1, 273-302.

Skamarock, W. C., R. Rotunno, and J. B. Klemp, 1999: Models of coastally trapped disturbances. J. Atmos. Sci., 56, 3349-3365.

Stensrud, D. J., R. L. Gall, S. L. Mullen, and K. W. Howard, 1995: Model climatology of the Mexican monsoon. J. Climate, 8 , 1775-1794.

, -, and M. K. Nordquist, 1997: Surges over the Gulf of California during the Mexican monsoon. Mon. Wea. Rev., 125, 417-437.

Wilks, D. S., 1995: Statistical Methods in the Atmospheric Sciences. Academic Press, 467 pp. 